\title{
チヤの新芽の熟度判定法
}

静岡県茶業試験場 此 本 晴 夫

\section{A Method of Judging the Maturity of New Tea Shoots}

\author{
By Haruo Konomoto
}

Shizuoka Tea Experiment Station

\section{1 まえがき}

チャの摘採適期は, 収量と品質の両而から判断しなく てはならない。収量は摘採期が途れるに従って增加する し，品質は逆化低下する。収量が多く，品質もよい特期 に摘採するために，その時期を判定する方法について は，いろいろ研究さ机ている。

そのなかて，農林水座省茶業試験場において，出開度 と収量, 品質との関係汸つて研究かなされ, 茶望の熟 度を判定するのに適当であると報告されている。その後 は出開度が広く利用されている。

出開度による熟度の判定法は非常にすぐれた方法であ るが，樹勢がよく出開きの進まない茶園や品種では，利 用し難い場合すある。また，出開度を調查することは妿 カがかかること，活場で判断し難いなどの問題もある。

より簡易な方法で茶芽の熟度を判定する方法があれ ば，一般農家が時期を判定するのに便利であり，一方， 試験研究を行っていく上でる, 調查を能率的行行るる のと思われる。

そこで，新芽の先端に打もりをつるし，茎 の曲りの程度を測定することによって, 蔆の 硬化の程度を測る方法を試みた。その結果， 出開度々同程度に利用でき，測定も容易であ ると思われたので，ここ坢告し，大方のご 批判を仰ぐ次第である。

\section{2 試 験 方 法}

するがわせ，やぶきた，くらさわ，ふじみ どりの 4 品種を供武し，出開度で 30〜90\% の闒任 4 回摘採炎行い, 収量, 収量構成, 品 質を調查した。同時に，各摘採時の出開度， 硬化度 (仮称) を調查した。

新芽の硬化度の調查は, 各区からランダム （生育の恶い芽は除く）に 15 本（1977年）ま
たは20本 (1978年)の澵芽を基部から摘みとり，その先 端に重り $(9.42 \mathrm{~g})$ をつるし，甚部からわん曲した中央 までの長さ (b)を新芽長 (a)で除して100倍した（図 1)。

収量調查は，カッタ一式の小型動力摘採機を用いて, 1 区 $5.4 \mathrm{~m}^{2}$ を 3 反復して摘採した。

わく摘み調查は， $30 \mathrm{~cm} \times 30 \mathrm{~cm}$ のわくを用いて， 1 区で2カ所，らねの頂部で行った。

品㣱調査は，収量調查を行った 3 区の5ちの 2 区につ いて， $2 \mathrm{~K}$ 機にて製造し，標準審查法によって密查し た。

\section{3 試 験 結 果}

\section{1 気象および生育状況}

表 1 に示すよ5に 1977 年は 3 月中旬以降の気温が高 く，萠芽は早まった。その後の生青も順調て摘採も早李 った。捅採期間の天候も比較的良好であった。1978 年は, 3 月中旬以降の気温がやや低く, 萌芽は遅れ, その後の気 温子やや低く，摘採期は退れた。摘採期間の天候は 5 月
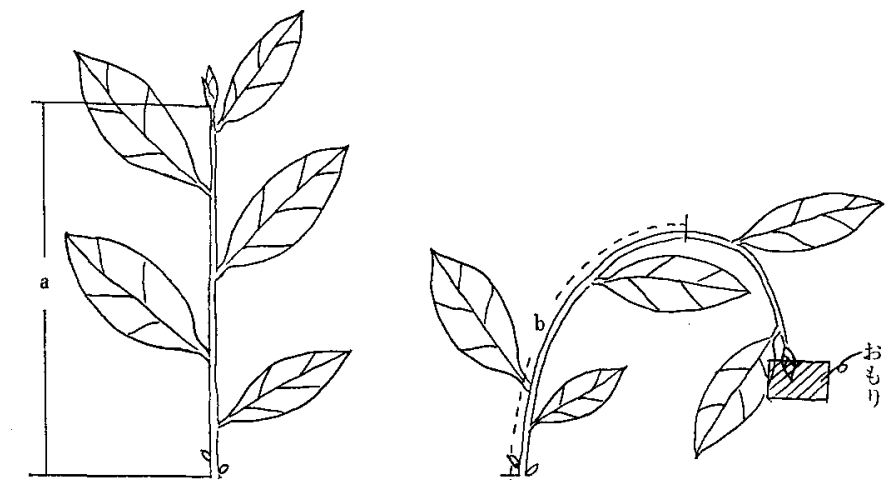

図1 硬 化度 の 測 定法 
茶柴 矿栄報告

表1 符象状況

\begin{tabular}{|c|c|c|c|c|c|c|c|c|c|c|c|c|}
\hline \multirow{2}{*}{ 月 項目 } & \multicolumn{6}{|c|}{$\begin{array}{lllll}1 & 9 & 7 & 7 & \text { 年 }\end{array}$} & \multicolumn{6}{|c|}{$\begin{array}{lllll}19 & 9 & 8 & \text { 年 } \\
\end{array}$} \\
\hline & $\begin{array}{ll}\text { 鼓 } & \text { 高 } \\
\text { 艾 } & \text { 㴓 } \\
\end{array}$ & $\begin{array}{ll}\text { 最 低 } \\
\text { 温 } \\
\end{array}$ & $\begin{array}{ll}\text { 平均 } \\
\text { 気 湍 }\end{array}$ & $\begin{array}{c}\text { 照 } \\
\text { 照 }\end{array}$ & 日射量 & 降水量 & 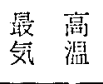 & $\begin{array}{ll}\text { 最 低 } \\
\text { 気 湿 }\end{array}$ & $\begin{array}{cc}\text { 平 } & \text { 圽 } \\
\text { 幾 温 }\end{array}$ & 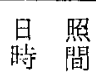 & 日射量 & 降水量 \\
\hline $\begin{array}{l}\text { 月 } \\
4.21\end{array}$ & $\begin{array}{l}{ }^{\circ} \mathrm{C} \\
24.6\end{array}$ & $\begin{array}{l}{ }^{\circ} \mathrm{C} \\
8.8\end{array}$ & $\begin{array}{l}{ }^{\circ} \mathrm{C} \\
16.7\end{array}$ & 11.5 & $\underset{577}{\mathrm{cal} / \mathrm{cm}^{2}}$ & $\underline{\mathrm{mm}}$ & ${ }^{\circ} \mathrm{C}$ & ${ }^{\circ} \mathrm{C}$ & ${ }^{\circ} \mathrm{C}$ & $\mathrm{h}$ & $\mathrm{cal} / \mathrm{m}^{2}$ & $\overline{\mathrm{mm}}$ \\
\hline 22 & 19.8 & 10.3 & 15.1 & 9.4 & 459 & & & & & & & \\
\hline 23 & 24.9 & 9.2 & 17.1 & 11.4 & 556 & & & & & & & \\
\hline 24 & 21.4 & 11.1 & 16.3 & 7.5 & 316 & 3.0 & & & & & & \\
\hline 25 & 20.5 & 13.7 & 17.1 & 0 & 30 & 58.0 & & & & & & \\
\hline 26 & 23.6 & 14.8 & 19.2 & 5.8 & 460 & & & & & & & \\
\hline 27 & 20.8 & 13.3 & 17.1 & 8.8 & 391 & 18.0 & & & & & & \\
\hline 28 & 19.9 & 13.5 & 16.7 & 0.8 & 74 & 3.0 & 23.3 & 8.7 & 16.0 & 9.2 & 549 & 3.5 \\
\hline 29 & 20.5 & 10.1 & 15.3 & 10.9 & 593 & & 15.1 & 12.8 & 14.0 & - & 42 & 15.0 \\
\hline 30 & 17.5 & 7.4 & 12.5 & 11.0 & 553 & & 19.4 & 12.8 & 16.1 & 0.1 & 122 & 6.5 \\
\hline $5 \cdot 1$ & 20.4 & 8.5 & 14.5 & 11.8 & 618 & 28.5 & 20.2 & 15.1 & 17.7 & 0.9 & 186 & 12.5 \\
\hline 2 & 20.6 & 13.3 & 17.0 & 0.1 & 28 & 29.0 & 23.4 & 17.4 & 20.4 & 9.4 & 683 & - \\
\hline 3 & 24.2 & 13.0 & 18.6 & 12.3 & 638 & - & 21.3 & 8.2 & 14.8 & 9.6 & 488 & - \\
\hline 4 & 16.8 & 13.6 & 15.2 & 1.0 & 193 & 16.0 & 23.8 & 10.7 & 17.3 & 7.6 & 485 & - \\
\hline 5 & 19.7 & 11.7 & 15.7 & 0 & 37 & 8.0 & 22.2 & 13.2 & 17.7 & 11.0 & 531 & - \\
\hline 6 & 25.8 & 12.9 & 19.4 & 12.0 & 464 & 0.0 & 16.8 & 14.9 & 15.9 & - & 107 & 15.0 \\
\hline 7 & 22.4 & 16.5 & 19.5 & 8.4 & 435 & & 17.9 & 9.3 & 13.6 & - & 176 & 8.5 \\
\hline 8 & 23.9 & 6.1 & 15.0 & 12.3 & 655 & & 20.7 & 10.8 & 15.8 & 7.7 & 578 & 0.5 \\
\hline 9 & 21.4 & 10.3 & 15.9 & 11.2 & 573 & & 20.0 & 15.2 & 17.6 & 2.4 & 200 & 8.5 \\
\hline 10 & & & & & & & 20.1 & 16.3 & 18.2 & 2.2 & 184 & 14.5 \\
\hline 11. & & & & & & & 18.9 & 16.3 & 17.6 & 0.1 & 102 & 7.0 \\
\hline 12 & & & & & & & 21.6 & 12.2 & 16.9 & 9.1 & 631 & - \\
\hline 13 & & & & & & & 22.2 & 13.8 & 18.0 & 8.3 & 507 & - \\
\hline 14 & & & & & & & 21.2 & 14.2 & 17.7 & 8.7 & 503 & - \\
\hline 15 & & & & & & & 23.9 & 11.5 & 17.7 & 11.4 & 707 & - \\
\hline 16 & & & & & & & 23.6 & 13.7 & 18.7 & 9.0 & 495 & 0.0 \\
\hline 17 & & & & & & & 23.2 & 15.2 & 19.2 & 5.8 & 411 & 1.0 \\
\hline 18 & & & & & & & 19.7 & 14.6 & 17.2 & - & 76 & 102.5 \\
\hline
\end{tabular}

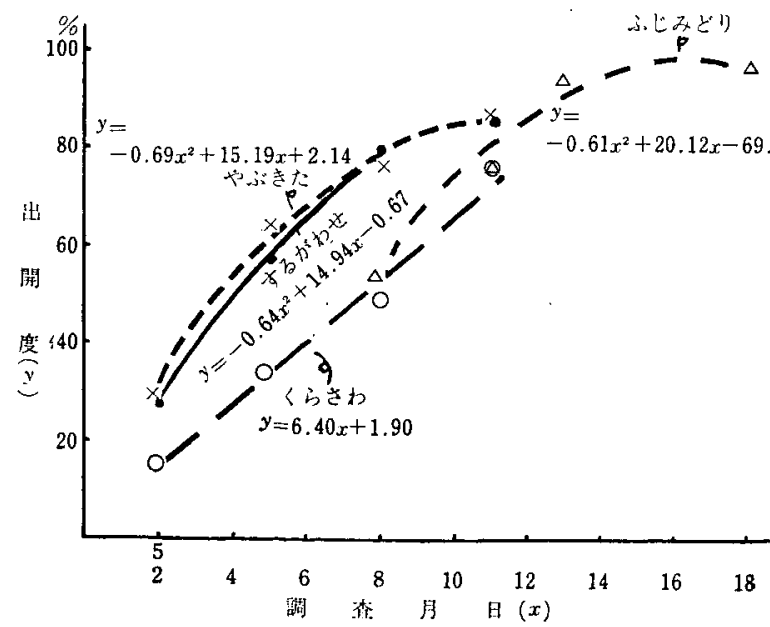

図2出開庭の経日变化 (1978)

注 $x$ は 5 月1日を1とした。

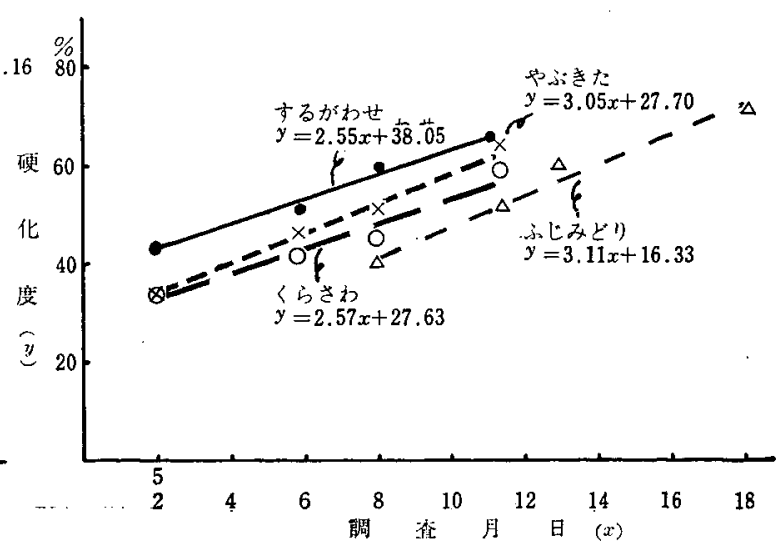

図3 硬化度の経日变化 （1978）

注 $x$ は 5 月1日を1とした。 
5日までは良かったが，ての後6日間屾等天が多かった。 こうした気像ならびに止青此沉のもとで武䮖を行った。

\section{2 出開度亡硬化度の経時変化}

供試した 4 品種について，4葉開葉期（ふじみどりは 5 渠開葉期) 上り出開度拈よび硬化度の経日的变化を图 2〜3に示した。いずれの品程も硬化度は直線的に变化 したが，出開度は曲線的増加した。同一摘採日の 3 区 を平均过ず，摘採日と硬化度および出開度との関係を表
2 に示した。いずれの品種も摘採が逯れるに徉って出開 度，破化度は增扣するが沚荓度より硬化度のほうが摘採 日との関係の樑いことがみられる。

\section{3 出開度と硬化度との関係}

出開度と硬化度との関係を表了汇示した。いずれの品 種も高い正の相関がみられる。

\section{4 収量調查の結果}

収量調查の結果を表 4 K示した。をの表をるとに，収

表2摘採日と硬化度扣よび出開度との関保

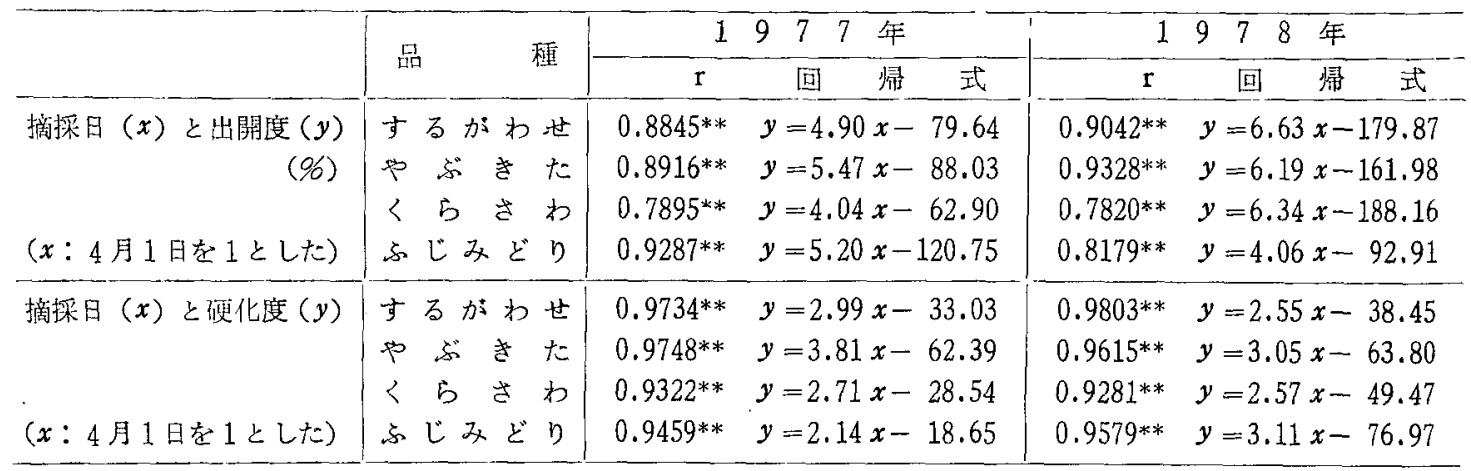

表3 硬化度と出開度之の関係

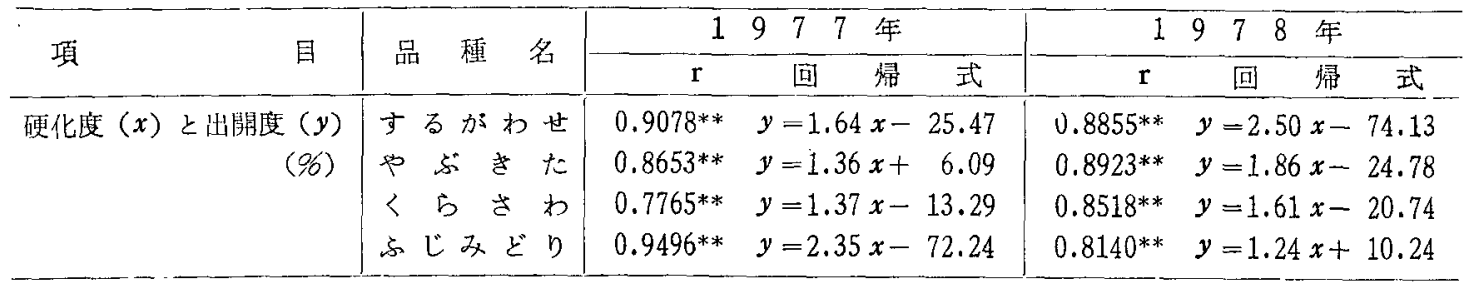

4-1 1977年の結棵

\begin{tabular}{|c|c|c|c|c|c|c|c|c|c|c|}
\hline \multirow{2}{*}{ 品＼cjkstart種＼cjkstart名 } & \multirow{2}{*}{ 摘採 日 } & \multirow{2}{*}{$\begin{array}{l}\text { わく摘 } \\
\text { み收量 }\end{array}$} & \multirow{2}{*}{$\begin{array}{l}900 \mathrm{~cm}^{2} \\
\text { 内芽数 }\end{array}$} & \multirow{2}{*}{100 芽 } & \multirow{2}{*}{ 出開度 } & \multirow{2}{*}{$\begin{array}{l}10 \text { a 当 } \\
\text { た } \\
\text { 双 悬 }\end{array}$} & \multirow{2}{*}{ 指 数 } & \multirow{2}{*}{ 硬化度 } & \multicolumn{2}{|c|}{$\begin{array}{l}\text { 硬化度を測定 } \\
\text { L芽 }\end{array}$} \\
\hline & & & & & & & & & 新芽長 & 葉 数 \\
\hline \multirow{4}{*}{ するがわ比 } & 4月26日 & $\begin{array}{r}g \\
53.7\end{array}$ & 170.5 & $\begin{array}{c}\mathrm{g} \\
31.6\end{array}$ & $4 \%$ & 437 & 100 & 43.1 & $\mathrm{~mm}$ & $\begin{array}{l}\text { 枚 } \\
4.0\end{array}$ \\
\hline & $29 日$ & 83.1 & 199.3 & 42.0 & 68 & 693 & 159 & 57.2 & 80.6 & 4.3 \\
\hline & 5 月 3 日 & 89.9 & 184.2 & 49.1 & 84 & 851 & 195 & 63.8 & 87.2 & 4.9 \\
\hline & 6日 & 122.7 & 199.2 & 62.4 & 94 & 1,110 & 254 & 75.2 & 90.5 & 4.7 \\
\hline \multirow{4}{*}{ やぶきた } & 4月26日 & 61.2 & 192.2 & 31.8 & 53 & 426 & 100 & 35.2 & 66.7 & 3.9 \\
\hline & 27日 & 74.4 & 196.2 & 38.2 & 60 & 530 & 124 & 39.0 & 72.8 & 4.0 \\
\hline & 30 日 & 88.0 & 201.3 & 44.1 & 77 & 699 & 164 & 54.5 & 75.8 & 4.1 \\
\hline & 5 月 3 日 & 99.1 & 206.2 & 48.3 & 92 & 801 & 188 & 60.9 & 68.8 & 4.8 \\
\hline \multirow{4}{*}{$<5 d わ$} & 4 月27日 & 55.5 & 185.2 & 29.9 & 45 & 311 & 100 & 42.9 & 71.5 & 4.0 \\
\hline & 30日 & 68.4 & 172.7 & 39.4 & 59 & 518 & 167 & 56.9 & 97.5 & 4.4 \\
\hline & 5 月 3 日 & 70.5 & 170.2 & 41.2 & 72 & 598 & 192 & 58.1 & 106.4 & 4.8 \\
\hline & 6日 & 91.5 & 177.0 & 52.5 & 81 & 720 & 232 & 69.6 & 101.3 & 4.9 \\
\hline \multirow{4}{*}{ ぶじみどり } & 4 月29日 & 61.3 & 131.7 & 41.3 & 28 & 343 & 100 & 41.9 & 95.3 & 5.0 \\
\hline & 5 月3日 & 69.1 & 150.5 & 46.2 & 53 & 444 & 129 & $53.3^{\circ}$ & 119.5 & 5.5 \\
\hline & 6 日 & 89.4 & 132.3 & 67.5 & 70 & 589 & 172 & 61.5 & 132.3 & 5.9 \\
\hline & 9 日 & 100.8 & 140.3 & 72.2 & 79 & 643 & 187 & 62.3 & 144.5 & 6.1 \\
\hline
\end{tabular}

表4 収量調查 
4-2 1978年の結果

\begin{tabular}{|c|c|c|c|c|c|c|c|c|c|c|}
\hline \multirow{2}{*}{ 品 棰 名 } & \multirow{2}{*}{ 摘操 日 } & \multirow{2}{*}{$\begin{array}{l}\text { わく摘又 } \\
\text { 収 量 }\end{array}$} & \multirow{2}{*}{$\begin{array}{l}900 \mathrm{~cm}^{2} \\
\text { 内芽数 }\end{array}$} & \multirow{2}{*}{ 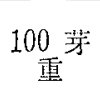 } & \multirow{2}{*}{ 出開度 } & \multirow{2}{*}{$\begin{array}{l}10 \mathrm{a} \text { 当 } \\
\text { た } \\
\text { 收 舅 }\end{array}$} & \multirow{2}{*}{ 指 数 } & \multirow{2}{*}{ 磂化度 } & \multicolumn{2}{|c|}{$\begin{array}{l}\text { 䂭化度を测定 } \\
\text { 七た芽の }\end{array}$} \\
\hline & & & & & & & & & 新芽長 & 望 数 \\
\hline \multirow{4}{*}{ るがわせ } & 5 月 2 日 & $\begin{array}{r}\mathrm{g} \\
47.1\end{array}$ & 155.2 & 30.3 & 27 & $\begin{array}{r}\mathrm{kg} \\
496\end{array}$ & 100 & $43 . \%$ & $\frac{\mathrm{mm}}{69.5}$ & $\begin{array}{l}\text { 枚 } \\
4.3\end{array}$ \\
\hline & 5 日 & 69.0 & 170.8 & 40.5 & 57 & 698 & 141 & 50.1 & 84.8 & 4.7 \\
\hline & 8 日 & 81.4 & 183.8 & 44.4 & 79 & 881 & 178 & 59.2 & 92.3 & 5.3 \\
\hline & 11日 & 100.3 & 163.5 & 61.6 & 86 & 1,073 & 216 & 65.8 & 113.7 & 5.3 \\
\hline \multirow{4}{*}{ ぶきた } & 5 月 2 日 & 41.4 & 138.2 & 30.0 & 29 & 406 & 100 & 34.4 & 75.7 & 3.9 \\
\hline & 5 日 & 56.5 & 141.8 & 39.7 & 63 & 454 & 112 & 43.4 & 84.1 & $4.5^{\circ}$ \\
\hline & 8 日 & 72.7 & 150.5 & 48.4 & 77 & 620 & 153 & 50.3 & 82.2 & 4.7 \\
\hline & 11日 & 81.0 & 134.5 & 60.1 & 86 & 834 & 205 & 62.7 & 107.7 & 5.2 \\
\hline \multirow{4}{*}{$<b さ わ$} & 5 月 2 日 & 31.6 & 125.7 & 25.7 & 16 & 257 & 100 & 33.5 & 54.7 & 3.9 \\
\hline & 5 日 & 42.3 & 138.7 & 31.5 & 34 & 381 & 148 & 40.1 & 74.5 & 4.4 \\
\hline & 8 日 & 52.4 & 125.2 & 41.9 & 49 & 522 & 203 & 46.1 & 80.0 & 4.4 \\
\hline & 11日 & 76.1 & 142.8 & 54.0 & 75 & 724 & 282 & 57.2 & 99.3 & 5.0 \\
\hline \multirow{4}{*}{ ぶじみど゙り } & 5 月 8 日 & 39.7 & 104.0 & 38.2 & 54 & 358 & 100 & 40.4 & 69.9 & 4.9 \\
\hline & 11日 & 53.3 & 108.5 & 49.4 & 75 & 448 & 125 & 50.4 & 95.2 & 5.4 \\
\hline & 13日 & 72.2 & 114.0 & 63.1 & 93 & 530 & 148 & 59.2 & 107.2 & 5.6 \\
\hline & 18日 & 72.9 & 94.7 & 76.8 & 96 & 728 & 203 & 71.4 & 111.0 & 5.8 \\
\hline
\end{tabular}

表 5 出開度および硬化度と収量との関係

\begin{tabular}{|c|c|c|c|}
\hline 胉 & & 19977 年 & 1978 年 \\
\hline 算 & & 回 & 式 \\
\hline $\begin{array}{r}\text { 背開度 }(x) \text { と収量 }(y) \\
\text { \% }(\mathrm{kg} / 10 \mathrm{a})\end{array}$ & $\begin{array}{l}\text { するがわせ } \\
\text { や゙゙きた } \\
く \text { らさ } \\
\text { ふじみどり }\end{array}$ & $\begin{array}{ll}0.8789^{* *} & y=10.36 x+22.99 \\
0.8190^{* *} & y=7.58 x+79.90 \\
0.7601^{* *} & y=7.02 x+83.65 \\
0.8629^{* *} & y=5.06 x+219.38\end{array}$ & $\begin{array}{l}0.8734^{* *} y=7.74 x+305.12 \\
0.8094^{* *} y=6.17 x+184.05 \\
0.8278^{* *} y=5.33 x+239.54 \\
0.7147^{* *} y=5.78 x+56.04\end{array}$ \\
\hline $\begin{array}{r}\text { 硬化度 }(x) \text { と収量 }(y) \\
(\mathrm{kg} / 10 \mathrm{a})\end{array}$ & 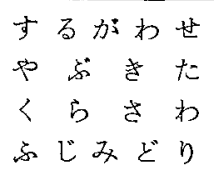 & $\begin{array}{ll}0.9737^{* *} & y=20.68 x-464.24 \\
0.9335^{* *} & y=13.56 x-28.76 \\
0.8614^{* *} & y=14.01 x-260.51 \\
0.9078^{* *} & y=13.01 x-198.11\end{array}$ & $\begin{array}{ll}0.9505^{* *} & y=23.76 x-510.14 \\
0.9520^{* *} & y=15.16 x-144.24 \\
0.9217^{* *} & y=17.51 x-303.28 \\
0.8341^{* *} & y=10.30 x-54.35\end{array}$ \\
\hline
\end{tabular}

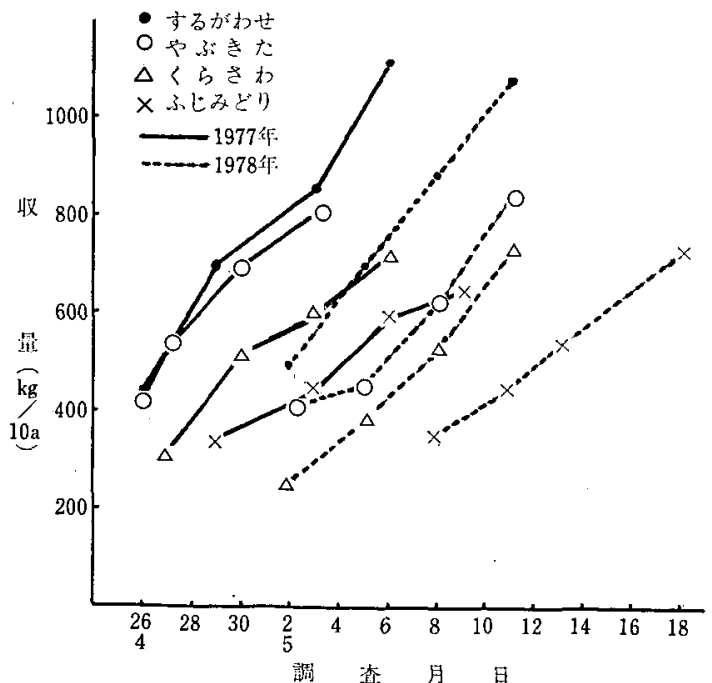

図4 収量の経 日变 化

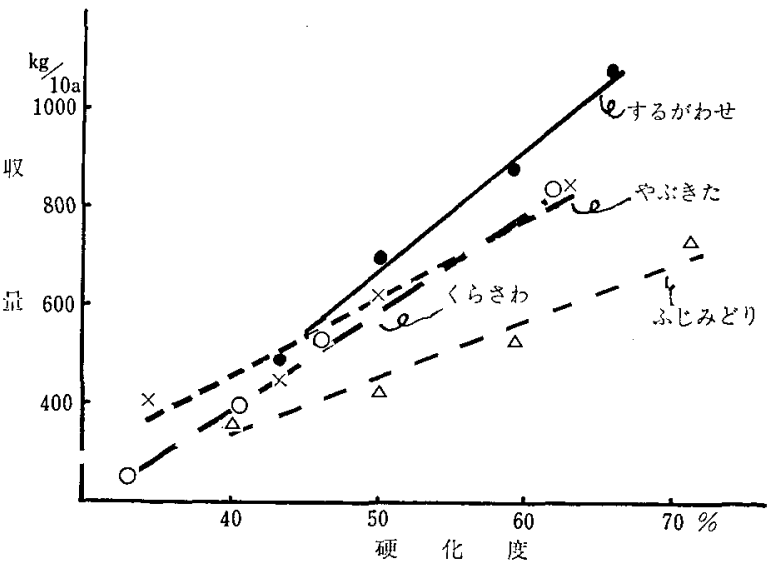

図 5 硬化度と収量 
冒の経日変化を図4に示した。いずれの品種もほ医䦽線

・的に堌加した。

硬化度拉よび出開度と仪量との関係を図 $5 \sim 6$ に示し た。反復した区左均せずに，硬化度拈よび法開度と収

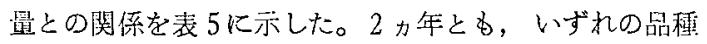
も, 硬化度と収量之の相関の注らが, 出開度と収量の相 関より高い。

\section{5 品質 調 查}

1977年の品質調查の結思を表 6に示し, 硬化度括よび 出開度と審查点数との関係を表 7 に示した。いずれの品 種も，莴い負の相関がみられた。硬化度と審查点数との 関係は，出阙度と品質との関係より㛑密である。

\section{6 硬化度の変動係数}

1区からランダムに 20本の芽を摘みとり，3区のもの をひとまとめにして計 60本について硬化度を調べ，その

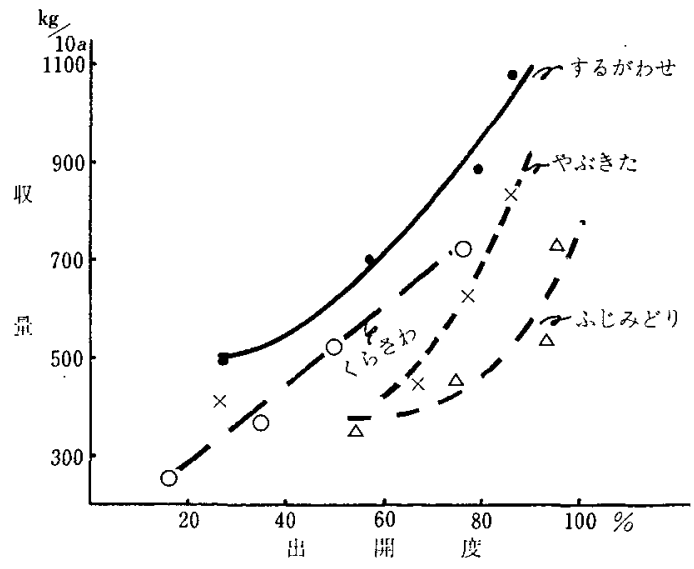

図6 出開度と収㫜

表6 品質調查（1977）

\begin{tabular}{|c|c|c|c|c|c|c|c|c|c|c|}
\hline \multirow{2}{*}{ 品 種 名 } & \multirow{2}{*}{ 摘採日 } & \multicolumn{3}{|l|}{ 外 } & \multicolumn{4}{|c|}{ 内 } & \multirow{2}{*}{ 合 計 } & \multirow{2}{*}{ 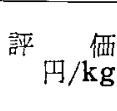 } \\
\hline & & 形 状 & 色 沢 & 計 & 香 気 & 水 色 & 嵫 味 & 計 & & \\
\hline \multirow{4}{*}{ がわ } & 4 月 26 日 & 15.0 & 14.3 & 29.3 & 15.0 & 15.0 & 15.5 & 45.5 & 74.8 & 4,450 \\
\hline & & 12.0 & 13.8 & 25.8 & 14.0 & 14.0 & 14.5 & 42.5 & 68.3 & 3,100 \\
\hline & 5 月 3 日 & 10.0 & 11.0 & 21.0 & 10.5 & 13.0 & 13.5 & 37.0 & 58.0 & 2,000 \\
\hline & 6 日 & 9.0 & 9.5 & 18.5 & 9.0 & 12.0 & 10.0 & 31.0 & 49.5 & 2,200 \\
\hline \multirow{4}{*}{ やぶきた } & 4 月26日 & 17.0 & 16.0 & 33.0 & 16.0 & 16.0 & 17.0 & 49.0 & 82.0 & 5,300 \\
\hline & 27日 & 16.0 & 16.0 & 32.0 & 15.5 & 15.0 & 16.0 & 46.5 & 78.5 & 5,050 \\
\hline & 30 日 & 12.5 & 15.0 & 27.5 & 14.0 & 14.0 & 12.5 & 40.5 & 68.0 & 3,350 \\
\hline & 5月 3 日 & 10.5 & 13.5 & 24.0 & 12.0 & 12.0 & 11.0 & 35.0 & 59.0 & 2,750 \\
\hline \multirow{4}{*}{$<b$ 放 } & 4月27日 & 17.3 & 16.8 & 34.0 & 15.8 & 14.5 & 11.0 & 41.3 & 75.3 & 4,250 \\
\hline & 30 日 & 14.5 & 15.3 & 29.8 & 14.0 & 14.0 & 10.0 & 38.0 & 67.8 & 3,750 \\
\hline & 5 月 3 日 & 13.5 & 14.3 & 27.8 & 12.3 & 13.0 & 9.0 & 34.3 & 62.0 & 2,470 \\
\hline & 6日 & 11.5 & 12.5 & 24.0 & 10.5 & 12.0 & 6.5 & 29.0 & 53.0 & 2,350 \\
\hline \multirow{4}{*}{ ふじみどり } & 4 月29日 & 14.5 & 10.8 & 25.3 & 13.0 & 15.0 & 15.0 & 43.0 & 68.3 & 3,150 \\
\hline & 5 月 3 日 & 12.0 & 8.5 & 20.5 & 10.0 & 13.5 & 13.0 & 36.5 & 57.0 & 2,800 \\
\hline & 6 日 & 9.5 & 8.0 & 17.5 & 9.0 & 12.5 & 8.3 & 29.8 & 47.3 & 2,500 \\
\hline & 9 日 & 9.0 & 9.0 & 18.0 & 8.0 & 11.5 & 8.0 & 27.5 & 45.5 & 2,350 \\
\hline
\end{tabular}

表 7 硬化度, 出開度と品質との関係（1977年）

$7-1$ 出開度と番蒩点数

\begin{tabular}{|c|c|c|}
\hline するがせ & $8037^{* *}$ & $y=-0.385 x+90.614$ \\
\hline やぶきた & $r=-0$ & $513 x+108.366$ \\
\hline$<5 d わ$ & $\mathrm{r}=-0.7362^{* *}$ & $y=-0.523 x+99.247$ \\
\hline ふじみどり & $\mathrm{r}=-0.9639 * *$ & $y=-0.426 x+79.225$ \\
\hline
\end{tabular}

\begin{tabular}{|c|c|c|}
\hline するがわせ & $\mathrm{r}=-0.9634 * *$ & $y=-0.828 x+112.341$ \\
\hline やぶさた & $\mathrm{r}=-0.9945^{* *}$ & $y=-0.867 x+113.226$ \\
\hline$<5 さ わ$ & $\mathrm{r}=-0.8992^{* *}$ & $y=-0.753 x+107.031$ \\
\hline らじみどり & $\mathrm{r}=-0.9883^{*} *$ & $y=-1.011 x+110.255$ \\
\hline
\end{tabular}




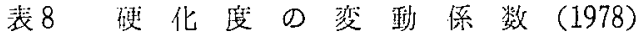

\begin{tabular}{|c|c|c|c|c|c|c|c|c|c|}
\hline 品 & 品 種 & 名 & 摘 採 日 & 新 芽 長 & 変動 係数 & 葉 & 変 動 係数 & 硬 化 度 & 変動 係数 \\
\hline 士 & る が & わ过 & $\begin{array}{c}5 \text { 月 } 2 \text { 日 } \\
5 \\
8 \\
11 \\
\end{array}$ & $\begin{array}{c}\mathrm{mm} \\
69.5 \\
84.8 \\
92.3 \\
113.7\end{array}$ & $\begin{array}{l}23.9 \\
20.8 \\
22.9 \\
23.8\end{array}$ & $\begin{array}{l}\text { 枚 } \\
4.3 \\
4.6 \\
5.2 \\
5.3\end{array}$ & $\begin{array}{l}\% \\
12.6 \\
11.5 \\
11.9 \\
10.0\end{array}$ & $\begin{array}{l}0 \% \\
43.3 \\
50.1 \\
59.2 \\
65.8\end{array}$ & $\begin{array}{l}\% \\
15.7 \\
15.3 \\
14.2 \\
10.2\end{array}$ \\
\hline & ぶ & * & $\begin{array}{c}2 \\
5 \\
8 \\
11 .\end{array}$ & $\begin{array}{r}74.6 \\
84.3 \\
82.3 \\
107.6 \\
\end{array}$ & $\begin{array}{l}22.2 \\
18.0 \\
21.0 \\
22.2 \\
\end{array}$ & $\begin{array}{l}3.9 \\
4.5 \\
4.6 \\
5.2 \\
\end{array}$ & $\begin{array}{l}15.4 \\
13.8 \\
13.9 \\
11.7 \\
\end{array}$ & $\begin{array}{l}34.4 \\
43.3 \\
50.1 \\
62.7\end{array}$ & $\begin{array}{l}19.0 \\
15.7 \\
17.9 \\
12.2\end{array}$ \\
\hline$<$ & 5 & さ & $\begin{array}{c}2 \\
5 \\
8 \\
11 \\
\end{array}$ & $\begin{array}{l}54.7 \\
74.5 \\
80.0 \\
99.2 \\
\end{array}$ & $\begin{array}{l}22.9 \\
19.5 \\
22.3 \\
23.8 \\
\end{array}$ & $\begin{array}{l}3.9 \\
4.3 \\
4.4 \\
5.0\end{array}$ & $\begin{array}{l}16.2 \\
13.3 \\
12.7 \\
10.8 \\
\end{array}$ & $\begin{array}{l}33.5 \\
39.4 \\
46.0 \\
57.2 \\
\end{array}$ & $\begin{array}{l}14.9 \\
21.6 \\
19.3 \\
13.1 \\
\end{array}$ \\
\hline s. & じ み & $\xi ゙ り$ & $\begin{array}{c}8 \\
11 \\
13 \\
18\end{array}$ & $\begin{array}{r}69.9 \\
95.2 \\
107.2 \\
111.0\end{array}$ & $\begin{array}{l}29.5 \\
28.9 \\
25.9 \\
31.6\end{array}$ & $\begin{array}{l}4.9 \\
5.4 \\
5.6 \\
5.8\end{array}$ & $\begin{array}{l}10.6 \\
12.3 \\
11.4 \\
13.8\end{array}$ & $\begin{array}{l}40.4 \\
50.4 \\
59.4 \\
71.4\end{array}$ & $\begin{array}{r}24.1 \\
8.7 \\
12.1 \\
9.7\end{array}$ \\
\hline
\end{tabular}

表 9 おもりの重さを变えた場合の硬化度の変化（1978）

\begin{tabular}{|c|c|c|c|c|c|c|}
\hline \multirow{2}{*}{ 種 } & \multirow{2}{*}{$\mathrm{mm}$} & \multirow{2}{*}{ 葉 } & \multicolumn{2}{|c|}{ 挍 } & 重 & さ \\
\hline & & & $3.25 \mathrm{~g}$ & $6.16 \mathrm{~g}$ & $9.27 \mathrm{~g}$ & $14.32 \mathrm{~g}$ \\
\hline 之 & $95.3^{\mathrm{mm}}$ & $4.5^{\text {枚 }}$ & 71 & 60 & 46 & 28 \\
\hline するがわせ & 89.9 & 4.3 & 63 & 54 & 46 & 21 \\
\hline や 市 & 59.5 & 3.2 & 66 & 54 & 44 & 33 \\
\hline や ぶきた & 92.5 & 4.0 & 68 & 61 & 51 & 34 \\
\hline$く ら$ む わ & 69.3 & 3.8 & 66 & 53 & 42 & 29 \\
\hline ふ じみ どり & 99.4 & 4.0 & 52 & 40 & 34 & 23 \\
\hline かなやみどり & 52.7 & 3.1 & 59 & 47 & 38 & 26 \\
\hline 均 & 79.8 & 3.8 & 63.6 & 52.7 & 43.0 & 27.7 \\
\hline
\end{tabular}

重さ $(x)$ と硬化度 $(y)$ との関䋆 $y=-3.21 x+73.23\left(\mathrm{r}=-0.9988^{* *}\right)$

変動係数を求めて表 8 に示した。便化度の変動係数は,

1，2の例外はあるが活汪 10〜20\%6程度である。

\section{7 おむりの重さ之硬化度との関係}

硬化度を測定する場合のおるりを变えて調查した結果 を表9に示した。打すりの重さと硬化度との間灿高い

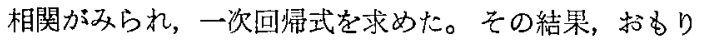
の重さが 3 15g の間では，拈もりが $3 \mathrm{~g}$ 重くなるごと に硬化度は $10 \%$ 程度小さくなる。

\section{4 考察}

チャの新芽の熟度を判定する有力な万法として，出閒 度があり，広く利用されている。しかし，その調査に当 たっては，わく摘みを行い，出開芽と末開芽を分讨て芽 数を調べなくてはならないので，労力がかかるのと出開 芽の見分けかたがやや難しい。そこで，誰にでもでき
て，測定者による詥差の生じ難い方法について，いろい ろ模索するなかで，新芽の先端に重りをつるし，曲りの 程度（硬化度とした）を測定する方法が，比倝的測定に 容易であると思われたので，出開度による方法と比較し た。

まず，出開き始めた後の出開度と硬化度の経日变化を 調查した結果, 出開度は抢よそ85\%程度むでは直線的に 增加する。こ机は原田らも指摘しているところである。 その後は曲線的に変化する。一方, 硬化度は出開度が 90 宆を過ざて直線的に増加する。そのため，熟度が進ん で出開度が 9096を越しても，硬化度は效度を表わすこと が可能であると思われた。

出開度と硬化度との相関は，いずれの品程も高かった。 しかし，出開度が $80 \%$ を越したものが入ってくると，そ の相関は低下する。出開度が 3096から80\%をでであれ 


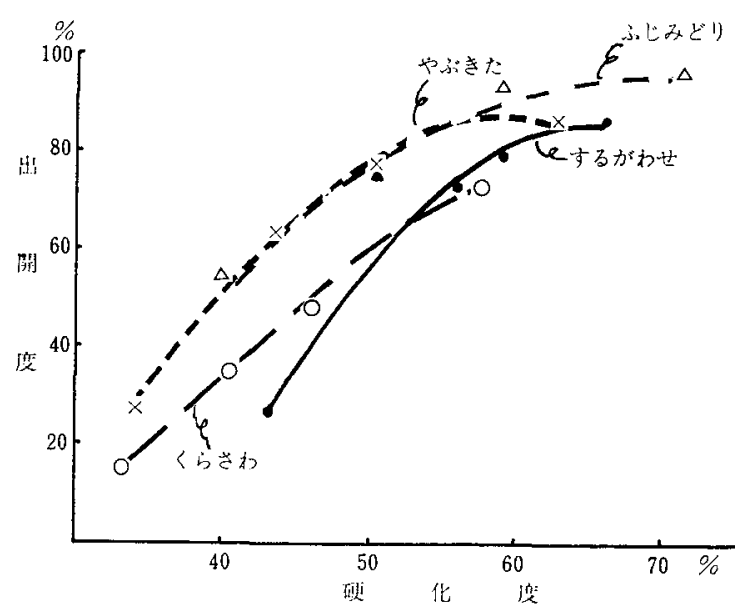

図7硬化度々出開度

ば，屾開度を硬化度に䠄き撸えることができるし，出開 度が 8096越した場合は硬化度で示した方が適していると 思われる（因 7)。

収量の経日的变化をみると，いずれの品種も直線的に 增加して㧊り, 出開度が 90\%を越してすな拈直線的火增 している。

出開度と収量, 硬化度と収量との相関をとってみる と，いずれの品種る，硬化度と収量との相関の活らが出 開度と収量との相関よりる高い。これは図 5 にみら机る ように，出開度と収量との関係は㽖線的であるためであ る。

硬化度あるいは出開度と荒茶の蕃査点数との関係をみ ると，1977 年の結果では出開度括よび硬化度と勫査点と の相関は高く，雨者の比較では硬化度の方が相関が高 い。1978年は, 洁開度も硬化度も勫查点数との相関はみ られなかった。品質との関係については今後更に榆討し なくてはなら务い。しかし, 出開度と硬化度との関保が 深いこと，出開度が90\%を越しても同じょうな傾问で硬 化度が増加することからみて，品質ともかなり強い関係 があるものと思われる。実用的には9gの打るりを吕し て，50\%を中心として 40〜50\%の間に摘採すればよいる のと思われる。

次に，硬化度を調べるのに，新芽の数がどれくらい必 要であるかを検討した。供試した 4 品種の各摘採時の硬 化度の变動係数を求めてみると，10２0 96程度である。 变動係数が 15 程度であれば，必要調查個体数は約 20 本 である。出開度を調查する場合を考光てみると，出開度 与茶株面の位置炕上り異なることから，わく摘みを 5 〜 6か所は行わないと 正確な出開度を示すことは困難であ ๖े

硬化度を測定する場合，おすりの重さと硬化度との相

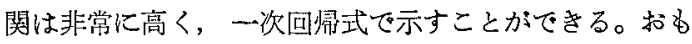

りの重さが 3〜15 g の間であれば，括もりが $3 \mathrm{~g}$ 增すと 涎化度は $10 \%$ 減少寸ることになる。みる芽の测定は $3 \mathrm{~g}$ 程度の呫鸟りを使い，熟度が進むに徉って，おすりの重 さを增やしていってるよいのではないかと思われる。

硬化度の利用については，今後実際にいるいるの状態 のものについて検討していく必要がある。また，摘子と らずに测定する方法を確立すれば，一般の農家の摘採適 期の判定に役立つるのと思われる。さらに, 試験研究に 拈ける省力化，あるい性葉品質の評価役立てること がでさればと考兄ている。

\section{5 摘要}

茶芽の熟度を判定する簡易な方法として，新芽の基の 硬さの程度を測定することを試みた。試験は 1977〜1978 年化，するがわせ，やぶきた，くらさわ，ふじみどりの 4 品種を供試して行った。

1 対象とする区から，新芽をランダムに 15 (1977年) 〜20（1978 年）を基部から摘みとり，その先端优すり (9,42 g の紙ばさみを利用) をつるし，基部からわん曲 した部分の中央までの長さを測り，新芽長で除し，100倍 した指数を求め, 硬化度と称した。

2 出開度で 30 90\% の間に 4 回摘採し, 収量, 品質, 出開度, 硬化度を調査したところ，摘採日と収量, 硬化 度との間には直線的な関係があり，出開度は 30〜80また は 90\%をなで直線的な関係があるが，その後は曲線的に なる。

3 硬化度と収量, 出開度と収量との相関はいずれも 高いが，硬化度の漂うが収睤との関係が強く，硬化度と 出開度との相関高い。

4 硬化度と品質との関係は, 出開度と品質との関係 と同様である。出開度が 90\%を越した場合は硬化度のほ らが適するものと思われる。

5 硬化度の変動係数は 10〜20であり，必要調查個 体数は 20 本程度である。

6 おるりの重さを変觉て硬化度を测定した場合，お まりの重さと硬化度との相関は高く $(\mathrm{r}=0.99 * *)$, 一次 式で示すことができ，おすりが $3 \sim 15 \mathrm{~g}$ のとは $3 \mathrm{~g}$ 增 すと硬化度は $10 \%$ 減少する。

7 硬化度は簡易に测定できるので，出開度と同様に 利用できるのではないかと思われる。しかし，品質との 関係は更に検討する必要がある。

本試験を行 5 に当たり，助言，協力をいたたいた当場 倉買幸一技師，品質調查をしていただいた柴田雄七主 幹，本報をとり末とめるに当たって愁切なるご指導を賜 った農林水産省茶業試験場茶樹第 3 研究室青野英也室長 に愿く批礼申し上げる。 


\section{6 引用文 献}

1）原田重婎, 増田清志, 安間 舞 : 東近農試研報 (茶), No. 7, 91 109 (1960).

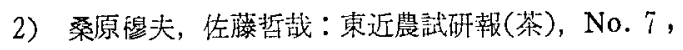
$110 \sim 129$ (1960).

3）鳥井秀一, 太田勇夫: 東近農試研報(茶), No. 7 , $130 \sim 142$ (1960).

4）此本啨失, 鈴木幸隆: 静岡茶陚研報, No. 8,19 $\sim 34$ (1977).

\section{Summary}

The easy method of judging the maturity of new tea shoots was investigated by surveying the degree of the hardness of the stem of new tea shoots, using four varieties (Surugawase, Yabukita, Kurasawa and Fujimidori) in 1977 and 1978.

The results are as follows.

1. Fifteen to 20 random samples were cut at the base of new tea shoots, weight of $9.42 \mathrm{gr}$ was hung at the top of shoot and the length to top from the base of the curved shoot was measured.

The degree of hardness of the shoots (D.H.S) was given as follows, length to top from the base of the curved shoot length of new shoot $\times 100=$ D. H. S

2. The results as to yield, quality, percentage of banjhi shoots to the total (P.B.S) and D.H.S, showed that P. B. S increased in curved line and the yield and P.H.S increased in straight line.

3. High positive correlations were observed between the yield and P.B.S, and the yield and D.H.S, and D.H.S was connected with the yield more closely than P.B.S.

4. The quality showed too high correlation to D.H.S and P.B.S, and when P.B.S was over $90 \%$, D.H.S was more suitable for judging the quality than P.B.S.

5. The coefficient of variation of D. H.S was 10 to 20 , and about 20 shoots were needed for samples.

6. When D.H.S was measured using various weights ( 3 to $15 \mathrm{gr}$ ), the correlation between D.H.S and weight was very high $(=0.99)$, and D.H.S decreased by $10 \%$ every 3 gr of increasing weight.

7. It may be given as a conclusion that D.H.S can be measured easily and used in the same way as P.B.S.

(Sep. 29, 1979) 